\title{
Naphthalene-based oligothiophene-stacked polymers
}

\author{
Yasuhiro Morisaki, Jonas Alves Fernandes and Yoshiki Chujo \\ We report the synthesis and properties of $\pi$-stacked polymers consisting of oligothiophene and naphthalene as the stacked \\ $\pi$-system and the scaffold, respectively. The titled polymers were obtained by the Suzuki-Miyaura coupling reaction. \\ Oligothiophene units were layered in proximity, $\sim 3.0 \AA$ from each other. Contribution of the quinoidal structure of the \\ oligothiophene units involving the naphthalene scaffolds in the excited state resulted in relatively high photoluminescence \\ quantum efficiencies. The polymers have potential application to optoelectronic devices such as hole-transporting materials. \\ Polymer Journal (2010) 42, 928-934; doi:10.1038/pj.2010.101; published online 27 October 2010
}

Keywords: conjugated polymers; $\pi$-stacked polymers; oligothiophene; redox polymers; synthesis

\section{INTRODUCTION}

Common conjugated polymers generally consist of $\mathrm{sp}$ - and/or $\mathrm{sp}^{2}$ carbon frameworks, and $\pi$-electrons are delocalized throughout the polymer backbone. Such conjugated polymers have attracted considerable attention because of their good processability and their readily tunable electronic and optical properties. ${ }^{1-3}$ Recently, a new type of conjugated polymer that exhibits through-space interactions of $\pi$ electron systems has been developed. Poly(dibenzofulvene)s, ${ }^{4-11} 7,7-$ diarylnorbornane-containing conjugated polymers, ${ }^{12,13}$ cyclophanecontaining polymers ${ }^{14-35}$ and face-to-face ferrocene polymers ${ }^{36-38}$ have been synthesized, and their optical and electrochemical properties have been studied in detail. Polymers with layered aromatic rings and $\pi$-electron systems have also been investigated; ${ }^{39-53}$ for example, Chen et al. ${ }^{53}$ recently reported the synthesis and formation of a twodimensional assembly of polymeric ladder phanes containing face-toface $\pi$-electron systems. These polymers have potential applications in optoelectronic devices and single-molecular devices such as singlemolecular wires.

Cofacially aligned $\pi$-electron systems have an important role in biochemistry and material chemistry; DNA has face-to-face base pairs stacked in the double-stranded main chains, ${ }^{54}$ and the performance of organic optoelectronic devices strongly depends on the arrangement of the $\pi$-electron systems. ${ }^{55}$ We have recently reported the synthesis of aromatic-ring-layered polymers using xanthene compounds as scaffolds. ${ }^{40-47}$ [2.2] Paracyclophane-layered polymers, which mimic multilayered cyclophanes, ${ }^{56-59}$ exhibited fluorescence resonance energy transfer from the layered paracyclophanes to the end-capping groups. The use of xanthene as a scaffold enabled us to introduce various aromatic compounds, such as phenylenes, ${ }^{44}$ carbazoles, ${ }^{45}$ thiophenes ${ }^{46}$ and anthracene, ${ }^{47}$ into the polymers, with the distance between the layered aromatic units being $\sim 4.5 \AA$. Our next target is to construct layered and $\pi$-stacked aromatic systems in proximity, less than the sum of the van der Waals radius $(3.40 \AA)$ of an $\mathrm{sp}^{2}$-carbon, in the polymer backbone.
Nakayama and co-workers ${ }^{60-62}$ and Iyoda and co-workers ${ }^{63,64}$ have reported the synthesis of cofacially oriented naphthalene-based oligothiophenes, in which two or three bithiophenes were layered. In addition, Iyoda and co-workers have synthesized 2,2'-bithiophenophanes. ${ }^{63,64}$ The layered bithiophenes in these compounds exhibit strong $\pi-\pi$ interactions. However, to the best of our knowledge, there has been no report on the synthesis of oligothiophene-stacked polymers. In this paper, we report the synthesis, characterization and properties of $\pi$-stacked polymers with oligothiophene as the $\pi$-stacked aromatic unit and naphthalene as the scaffold; these polymers were synthesized by the Suzuki-Miyaura coupling polymerization.

\section{EXPERIMENTAL PROCEDURE}

\section{General experimental details}

${ }^{1} \mathrm{H}$ and ${ }^{13} \mathrm{C}$ nuclear magnetic resonance (NMR) spectra were recorded on a JEOL JNM-EX400 instrument (JEOL, Tokyo, Japan) at 400 and $100 \mathrm{MHz}$, respectively. The chemical shift values were expressed relative to $\mathrm{Me}_{4} \mathrm{Si}$ as an internal standard. High-resolution mass spectra were obtained on a JEOL JMSSX102A spectrometer. Matrix-assisted laser desorption ionization time-of-flight mass spectroscopy measurement was performed on Voyager DE-STR (Applied Biosystems, Carlsbad, CA, USA) using all-trans-retinoic acid as a matrix. Gel permeation chromatography was carried out on a TOSOH 8020 (TSKgel G3000HXL column; Tosoh, Tokyo, Japan) instrument using $\mathrm{CHCl}_{3}$ as an eluent after calibration with standard polystyrene samples. Recyclable preparative high-performance liquid chromatography was performed on a Japan Analytical Industry (Tokyo, Japan), Model 918R (JAIGEL-2.5H and 3H columns) using $\mathrm{CHCl}_{3}$ as an eluent. UV-vis absorption spectra were obtained on a SHIMADZU UV3600 spectrophotometer (Shimadzu, Kyoto, Japan). Photoluminescence spectra were obtained on a Horiba FluoroMax-4 luminescence spectrometer (Horiba, Kyoto, Japan). Cyclic voltammetry was carried out on a BAS CV-50W electrochemical analyzer (BAS, Tokyo, Japan) in $\mathrm{CH}_{2} \mathrm{Cl}_{2}$ containing $0.1 \mathrm{~m}$ of sample and $0.1 \mathrm{M}$ of $\mathrm{BuNClO}_{4}$ with a glassy carbon working electrode, a Pt counter electrode, a $\mathrm{Ag} / \mathrm{AgCl}\left(\mathrm{Ag} / \mathrm{Ag}^{+}\right)$reference electrode and a ferrocene/ferrocenium $\left(\mathrm{Fc} / \mathrm{Fc}^{+}\right)$ external reference. Analytical thin-layer chromatography was performed with silica gel $60 \mathrm{Merck}_{254}$ plates. Column chromatography was performed with 
Wakogel C-300 silica gel. Elemental analyses were performed at the Microanalytical Center of Kyoto University.

\section{Materials}

Tetrahydrofuran (THF) and $\mathrm{Et}_{2} \mathrm{O}$ were purchased and purified by passage through purification column under Ar pressure. ${ }^{65}$ Dehydrated grade $\mathrm{CHCl}_{3}$ was purchased and used without further purification. $N, N, N^{\prime}, N^{\prime}$-tetramethylethylenediamine (TMEDA) was purchased commercially, and purified by distillation with KOH. 3-Hexylthiophene (1), $n$-butyllithium ( $n$-BuLi) $(1.6 \mathrm{M}$ in hexane), $s$-BuLi (1.0 M in cyclohexane and $n$-hexane), $\mathrm{ZnBr}_{2}, \mathrm{I}_{2}, \mathrm{Pd}\left(\mathrm{PPh}_{3}\right)_{4}$, $\mathrm{Pd}(\mathrm{OAc})_{2}$, 2-dicyclohexylphosphino-2',6'-dimethoxybiphenyl (S-Phos), $\mathrm{K}_{3} \mathrm{PO}_{4}, \mathrm{FeCl}_{3}$, bis(pinacolato)diboron (M1), 2,5-thiophenediboronic acid (M2) and 2,2-bithiophene-5,5'-diboronic acid bis(pinacol) ester (M4) were obtained commercially, and used without further purification. 1,8-Diiodonaphthalene $(2)^{66}$ and 2,5-bis(4,4,5,5-tetramethyl-1,3,2-dioxaborolan-2-yl)thieno[3,2-b-] thiophene (M3) ${ }^{67}$ were synthesized according to the literature's procedure. All reactions were performed under Ar atmosphere.

\section{1,8-Bis(4-hexylthien-2-yl)naphthalene (3)}

$1(3.6 \mathrm{ml}, .20 .0 \mathrm{mmol})$ in THF $(2.5 \mathrm{ml})$ was slowly added drop wise to $n$-BuLi $(1.6 \mathrm{M}$ in hexane, $6.3 \mathrm{ml}, 10.0 \mathrm{mmol})$ and TMEDA $(2.2 \mathrm{ml}, 15.0 \mathrm{mmol})$ in THF $(5.0 \mathrm{ml})$ at $-78^{\circ} \mathrm{C}$. After the solution was stirred at room temperature for $24 \mathrm{~h}$, $\mathrm{ZnBr}_{2}(9.0 \mathrm{~g}, 40.0 \mathrm{mmol})$ in THF $(20.0 \mathrm{ml})$ was transferred to this solution via a cannula at $0{ }^{\circ} \mathrm{C}$. The reaction mixture was stirred at room temperature for $24 \mathrm{~h}$. This solution was transferred via a cannula into a flask with $2(0.76 \mathrm{~g}, 2.0 \mathrm{mmol})$ and $\mathrm{Pd}\left(\mathrm{PPh}_{3}\right)_{4}(0.20 \mathrm{~g}, 0.17 \mathrm{mmol})$. After the reaction mixture was stirred at reflux temperature (oil bath temperature at $70{ }^{\circ} \mathrm{C}$ ) for $24 \mathrm{~h}, \mathrm{H}_{2} \mathrm{O}(30 \mathrm{ml})$ and $\mathrm{EtOH}(15 \mathrm{ml})$ were added to quench the reaction. The aqueous layer was washed with $\mathrm{CHCl}_{3}(25 \mathrm{ml})$ three times, and the organic layer was dried over $\mathrm{MgSO}_{4}$. After removal of $\mathrm{MgSO}_{4}$, the solvent was evaporated. The residue was subjected to column chromatography on $\mathrm{SiO}_{2}$ with hexane as an eluent to obtain $3(0.51 \mathrm{~g}, 1.1 \mathrm{mmol}, 57 \%)$ as a pale yellow oil.

$R_{\mathrm{f}} 0.21$ (hexane). ${ }^{1} \mathrm{H}$ NMR $\left(\mathrm{CDCl}_{3}, 400 \mathrm{MHz}\right): \delta=0.98\left(\mathrm{t}, J=6.4 \mathrm{~Hz},-\mathrm{CH}_{3}\right.$, $6 \mathrm{H}), 1.38\left(\mathrm{~m},-\mathrm{CH}_{2^{-}}, 12 \mathrm{H}\right), 1.54\left(\mathrm{~m},-\mathrm{CH}_{2^{-}}, 4 \mathrm{H}\right), 2.40\left(\mathrm{t}, J=7.6 \mathrm{~Hz},-\mathrm{CH}_{2^{-}}\right.$, $4 \mathrm{H}), 6.36(\mathrm{~s}$, thiophene $\mathrm{H}, 2 \mathrm{H}), 6.65(\mathrm{~s}$, thiophene $\mathrm{H}, 2 \mathrm{H}), 7.54(\mathrm{t}, J=7.6 \mathrm{~Hz}$, naphthalene $\mathrm{H}, 2 \mathrm{H}), 7.66(\mathrm{~d}, J=7.6 \mathrm{~Hz}$, naphthalene $\mathrm{H}, 2 \mathrm{H}), 7.92(\mathrm{~d}, J=8.4 \mathrm{~Hz}$, naphthalene $\mathrm{H}, 2 \mathrm{H})$ p.p.m. ${ }^{13} \mathrm{C} \mathrm{NMR}\left(\mathrm{CDCl}_{3}, 100 \mathrm{MHz}\right): \delta=14.1,22.6,29.2$, $29.9,30.3,31.7,118.0,125.0,128.9,129.0,130.3,132.0,132.8,135.4,142.7$, 143.4 p.p.m. High-resolution mass spectra (FAB): $m / z$ calcd. for $\mathrm{C}_{30} \mathrm{H}_{36} \mathrm{~S}_{2}$ $\left(\mathrm{M}^{+}\right)$: 460.2258, found: 460.2254. Anal. calcd. for $\mathrm{C}_{30} \mathrm{H}_{36} \mathrm{~S}_{2}$ : C 78.21; H 7.88; S 13.92, found: C 78.33; H 8.09; S 14.11.

\section{1,8-Bis(4-hexyl-5-iodothien-2-yl)naphthalene (4)}

$3(0.64 \mathrm{~g}, 1.4 \mathrm{mmol})$ in $\mathrm{Et}_{2} \mathrm{O}(15.0 \mathrm{ml})$ was slowly added drop wise to $s$-BuLi $(1.0 \mathrm{M}$ in cyclohexane and $n$-hexane, $10.0 \mathrm{ml}, 10.0 \mathrm{mmol})$ and TMEDA $(3.3 \mathrm{ml}$, $22.0 \mathrm{mmol}$ ) at $-78^{\circ} \mathrm{C}$. After the solution was stirred at room temperature for $24 \mathrm{~h}, \mathrm{I}_{2}(2.8 \mathrm{~g}, 11.0 \mathrm{mmol})$ in $\mathrm{Et}_{2} \mathrm{O}(15.0 \mathrm{ml})$ was transferred to this solution via a cannula at $-78^{\circ} \mathrm{C}$. The reaction mixture was stirred at room temperature for $24 \mathrm{~h}$. Saturated $\mathrm{Na}_{2} \mathrm{SO}_{3}$ aqueous $(30 \mathrm{ml}$ ) was added to quench the reaction. The aqueous layer was washed with $\mathrm{CHCl}_{3}$ three times, and the organic layer was dried over $\mathrm{MgSO}_{4}$. After removal of $\mathrm{MgSO}_{4}$, the solvent was evaporated. The residue was subjected to column chromatography on $\mathrm{SiO}_{2}$ with hexane as an eluent to obtain $4(0.60 \mathrm{~g}, 0.80 \mathrm{mmol}, 58 \%)$ as a pale yellow solid.

$R_{\mathrm{f}} 0.45$ (hexane). ${ }^{1} \mathrm{H}$ NMR $\left(\mathrm{CDCl}_{3}, 400 \mathrm{MHz}\right): \delta=0.89\left(\mathrm{t}, J=6.4 \mathrm{~Hz},-\mathrm{CH}_{3}\right.$, $6 \mathrm{H}), 1.32\left(\mathrm{~m},-\mathrm{CH}_{2^{-}}, 12 \mathrm{H}\right), 1.46\left(\mathrm{~m},-\mathrm{CH}_{2}-, 4 \mathrm{H}\right), 2.32\left(\mathrm{t}, J=7.6 \mathrm{~Hz},-\mathrm{CH}_{2^{-}}\right.$, $4 \mathrm{H}), 6.12(\mathrm{~s}$, thiophene $\mathrm{H}, 2 \mathrm{H}), 7.54(\mathrm{~m}$, naphthalene $\mathrm{H}, 4 \mathrm{H}), 7.94(\mathrm{~m}$, naphthalene $\mathrm{H}, 2 \mathrm{H})$ p.p.m. ${ }^{13} \mathrm{C} \mathrm{NMR}\left(\mathrm{CDCl}_{3}, 100 \mathrm{MHz}\right): \delta=14.3,23.1,29.6$, 30.1, 32.0, 32.8, 72.4, 125.4, 128.9, 129.9, 131.9, 132.5, 147.6, 148.5 p.p.m. Highresolution mass spectra (FAB): $\mathrm{m} / z$ calcd. for $\mathrm{C}_{30} \mathrm{H}_{34} \mathrm{I}_{2} \mathrm{~S}_{2}\left(\mathrm{M}^{+}\right)$: 712.0191, found: 712.0197. Anal. calcd. for $\mathrm{C}_{30} \mathrm{H}_{34} \mathrm{I}_{2} \mathrm{~S}_{2}$ : C 50.57; H 4.81; S 9.00, found: C $50.75 ;$ H 4.72 ; S 8.98

\section{1,8-Bis(2-thienyl)naphthalene (5)}

This compound was synthesized according to the procedure ${ }^{63,64}$ with some modifications. $\mathrm{ZnBr}_{2}$ was used instead of $\mathrm{ZnCl}_{2}$. The spectral data were matched with the literature's values. ${ }^{63,64}$
Yield $60 \% . R_{\mathrm{f}} 0.35$ (hexane). High-resolution mass spectra (EI (electron impact)): $\mathrm{m} / z$ calcd. for $\mathrm{C}_{18} \mathrm{H}_{12} \mathrm{~S}_{2}\left(\mathrm{M}^{+}\right): 292.0381$, found: 292.0380 . Anal. calcd. for $\mathrm{C}_{18} \mathrm{H}_{12} \mathrm{~S}_{2}$ : C 73.93; H 4.14; S 21.93, found: C 73.66; H 4.09; S 21.93 .

\section{Palladium-catalyzed coupling polymerization}

A typical procedure ${ }^{68-70}$ is as follows. Monomers $4(187.0 \mathrm{mg}, 0.20 \mathrm{mmol}), \mathbf{M} 2$ $(50.9 \mathrm{mg}, \quad 0.20 \mathrm{mmol}), \quad \mathrm{Pd}(\mathrm{OAc})_{2} \quad(4.5 \mathrm{mg}, 0.02 \mathrm{mmol}), \quad$ S-Phos $(8.2 \mathrm{mg}$, $0.02 \mathrm{mmol})$ and $\mathrm{K}_{3} \mathrm{PO}_{4}(169.8 \mathrm{mg}, 0.30 \mathrm{mmol})$ in THF $(4.0 \mathrm{ml})$ and $\mathrm{H}_{2} \mathrm{O}$ $(1.0 \mathrm{ml})$ were refluxed for $48 \mathrm{~h}$. After filtration by Celite, the solution was diluted in $\mathrm{CHCl}_{3}(20 \mathrm{ml})$ and washed twice with aqueous $\mathrm{NH}_{4} \mathrm{OH}(25 \mathrm{ml})$, brine $(25 \mathrm{ml})$, and $\mathrm{H}_{2} \mathrm{O}(25 \mathrm{ml})$. The organic layer was dried over $\mathrm{MgSO}_{4}$. After filtration, the solvent was evaporated. The crude product was dissolved in a small amount of $\mathrm{CHCl}_{3}$ and precipitated from $\mathrm{MeOH} /$ acetone three times. And then precipitation was repeated twice with $\mathrm{CHCl}_{3}$ and acetone to obtain polymer P2 (52.3 mg, $0.09 \mathrm{mmol}, 35 \%$ ).

Polymer P1. Yield: $10 \% .{ }^{1} \mathrm{H}$ NMR $\left(\mathrm{CD}_{2} \mathrm{Cl}_{2}, 400 \mathrm{MHz}\right): \delta=0.9$ (br), 1.3 (br m), 2.3 (br), 6.3-6.8 (br m), 7.6 (br), 7.9 (br) p.p.m. ${ }^{13} \mathrm{C}$ NMR $\left(\mathrm{CD}_{2} \mathrm{Cl}_{2}\right.$, $100 \mathrm{MHz}) \delta=14.3,23.1,29-31$ (m), 125 (m), 129-132 (m), 139.4, 141.8 p.p.m.

Polymer P2. Yield: $35 \% .{ }^{1} \mathrm{H}$ NMR $\left(\mathrm{CDCl}_{3}, 400 \mathrm{MHz}\right): \delta=0.8$ (br), 1.2 (br), 1.5 (br), 2.4 (br m), 6.4 (br), 7.0 (br), 7.6 (br m), 7.9 (br) p.p.m. ${ }^{13} \mathrm{C}$ NMR $\left(\mathrm{CDCl}_{3}, 100 \mathrm{MHz}\right): \delta=14.1,22.6,29-32(\mathrm{~m}), 34.9,130-132(\mathrm{~m}), 136,140$, 142 p.p.m.

Polymer P3. Yield: $71 \% .{ }^{1} \mathrm{H}$ NMR $\left(\mathrm{CD}_{2} \mathrm{Cl}_{2}, 400 \mathrm{MHz}\right): \delta=0.8$ (br m), 1.2 (br m), 1.5 (br m), 2.5 (br), 6.4 (br m), 7.2 (br m), 7.4-8.0 (br m) p.p.m. ${ }^{13} \mathrm{C}$ NMR $\left(\mathrm{CD}_{2} \mathrm{Cl}_{2}, 100 \mathrm{MHz}\right): \delta=14.3,23.1,29-32(\mathrm{~m}), 118,126,129-133(\mathrm{~m})$, 136-144 (m) p.p.m.

Polymer P4. Yield: $35 \% .{ }^{1} \mathrm{H}$ NMR $\left(\mathrm{CDCl}_{3}, 400 \mathrm{MHz}\right): \delta=0.8$ (br), $1.2(\mathrm{br})$, 1.5 (br), 2.5 (br), 6.4 (br m), 6.9 (br), 7.1 (br), 7.6 (br m), 7.9 (br) p.p.m. ${ }^{13} \mathrm{C}$ NMR $\left(\mathrm{CDCl}_{3}, 100 \mathrm{MHz}\right): \delta=14.1,22.7,29-32(\mathrm{~m}), 124(\mathrm{~m}), 125$ (m), 129-132 (m), $136(\mathrm{~m}), 142,143$ p.p.m

\section{Oxidative coupling polymerization}

Monomer $3(0.46 \mathrm{~g}, 1.0 \mathrm{mmol})$ was added to a mixture of $\mathrm{FeCl}_{3}(0.65 \mathrm{~g}$, $4.0 \mathrm{mmol})$ in $\mathrm{CHCl}_{3}(15 \mathrm{ml})$. The reaction mixture was stirred at reflux temperature (oil bath temperature at $70^{\circ} \mathrm{C}$ ) for $24 \mathrm{~h}$ and poured into a large amount of $\mathrm{MeOH}$ to obtain dark greenish-brown precipitates. The precipitates were washed with $\mathrm{MeOH}$ with a Soxhlet extractor for $48 \mathrm{~h}$ to yield a brown solid. The polymer was extracted from the precipitates with $\mathrm{CHCl}_{3}$ with the Soxhlet extractor for several hours to obtain a brown $\mathrm{CHCl}_{3}$ solution. The $\mathrm{CHCl}_{3}$ solution was washed with saturated aqueous $\mathrm{Na}_{2} \mathrm{~S}_{2} \mathrm{O}_{3}$ and aqueous $\mathrm{NH}_{3}$. And then, the $\mathrm{CHCl}_{3}$ solution was stirred with aqueous $\mathrm{H}_{2} \mathrm{NNH}_{2}$ for $6 \mathrm{~h}$. The $\mathrm{CHCl}_{3}$ solution was separated and dried over $\mathrm{MgSO}_{4}$. After removal of $\mathrm{MgSO}_{4}$, the solvent was evaporated to obtain a brown solid, which was dried in vacuo. The solid was dissolved in a small amount of $\mathrm{CHCl}_{3}$ and reprecipitated from a large amount of $\mathrm{MeOH}$ three times to obtain polymer $\mathbf{P 1}$ in the form of the brown powder ( $73.3 \mathrm{mg}, 0.16 \mathrm{mmol}, 16 \%)$.

\section{RESULTS AND DISCUSSION}

Scheme 1 outlines the synthetic route to the naphthalene-based monomer 4. The treatment of 1 with $n$-BuLi and TMEDA afforded 2-(4-hexylthienyl)lithium as an intermediate. The addition of $\mathrm{ZnBr}_{2}$ afforded a 2-(4-hexylthienyl)zinc bromide intermediate, and the successive Negishi coupling reaction ${ }^{71}$ with 2 in the presence of a catalytic amount of $\mathrm{Pd}\left(\mathrm{PPh}_{3}\right)_{4}$ yielded 3 in $57 \%$ isolated yield. Monomer 4 was obtained in $58 \%$ isolated yield by lithiation of 3 with $s$-BuLi/TMEDA, followed by iodination.

Target polymers P1-P4 were synthesized by polymerization of $\mathbf{4}$ and comonomers M1-M4 by the modified Suzuki-Miyaura coupling reaction ${ }^{68-70}$ in the presence of a catalytic amount of $\mathrm{Pd}(\mathrm{OAc})_{2}$ and a bulky phosphine ligand, 2-dicyclohexylphosphino-2',6'-dimethoxybiphenyl (S-Phos), with $\mathrm{K}_{3} \mathrm{PO}_{4}$ in $\mathrm{THF} / \mathrm{H}_{2} \mathrm{O}$ at reflux temperature for $48 \mathrm{~h}$, as shown in Scheme 2. Cyclic oligomers ${ }^{63,64}$ were not detected under this reaction condition because of the steric hindrance of pinacolborane moieties. The polymerization results are listed in 


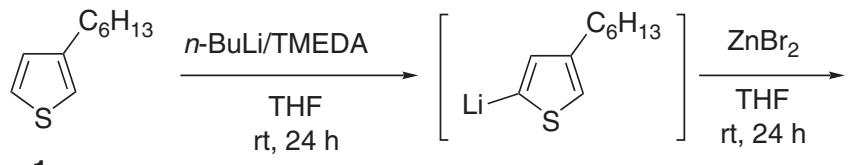

1

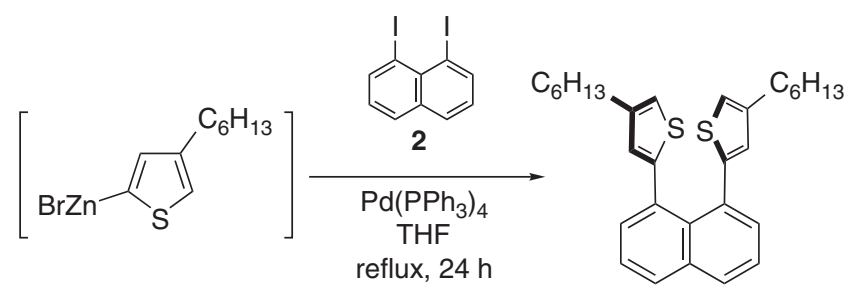

$3,57 \%$
1) $s$-BuLi/TMEDA

2) $\mathrm{I}_{2}$

$\mathrm{Et}_{2} \mathrm{O}$

$\mathrm{rt}, 48 \mathrm{~h}$

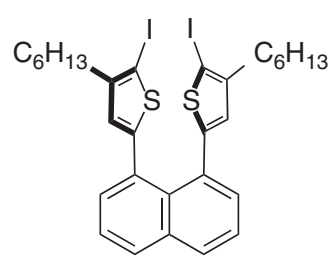

$4,58 \%$

Scheme 1 Synthesis of compounds $\mathbf{3}$ and $\mathbf{4}$.

Table 1. Polymer P1 with the head-to-head structure ${ }^{72}$ was also obtained by the oxidative coupling reaction of compound 3 with $\mathrm{FeCl}_{3}$ in $\mathrm{CHCl}_{3}$ (Scheme 3). The reaction of 3 with $\mathrm{FeCl}_{3}$ in $\mathrm{CHCl}_{3}$ afforded crude polymer $\mathbf{P 1}$ as a dark greenish-brown solid. This solid was purified with $\mathrm{MeOH}$ using a Soxhlet extractor; it was then treated with saturated aqueous $\mathrm{Na}_{2} \mathrm{~S}_{2} \mathrm{O}_{3}$, aqueous $\mathrm{NH}_{3}$, and aqueous $\mathrm{H}_{2} \mathrm{NNH}_{2}$ to remove iron species. The polymer solution was dried over $\mathrm{MgSO}_{4}$, and repeated reprecipitation was carried out to yield polymer P1 in 16\% isolated yield as a brown solid. However, we found a small amount of contamination by iron species $(\sim 1.3 \mathrm{wt} \%)$ in the polymer prepared by $\mathrm{FeCl}_{3}$-mediated oxidative coupling reaction (Supplementary Figure S13).

All polymers P1-P4 had good solubility in common organic solvents, such as cyclohexane, toluene, $\mathrm{CH}_{2} \mathrm{Cl}_{2}, \mathrm{CHCl}_{3}$ and THF.

Table 1 Results of polymerization

\begin{tabular}{lcccc}
\hline Entry & Polymer & Yield (\%) & $\mathrm{M}_{n}{ }^{\mathrm{b}}$ & $\mathrm{M}_{w} \mathrm{M}_{n}{ }^{\mathrm{b}}$ \\
\hline 1 & $\mathbf{P 1}$ & 10 & 1300 & 1.1 \\
2 & $\mathbf{P 2}$ & 35 & 2800 & 1.5 \\
3 & $\mathbf{P 3}$ & 71 & 3300 & 1.5 \\
4 & $\mathbf{P 4}$ & 35 & 3600 & 1.4 \\
\hline
\end{tabular}

alsolated yield.

bEstimated by gel permeation chromatography $\left(\mathrm{CHCl}_{3}\right)$ using polystyrene as standards.<smiles></smiles>

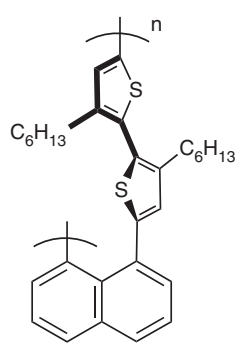

P1

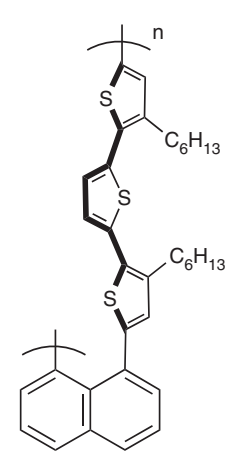

P2

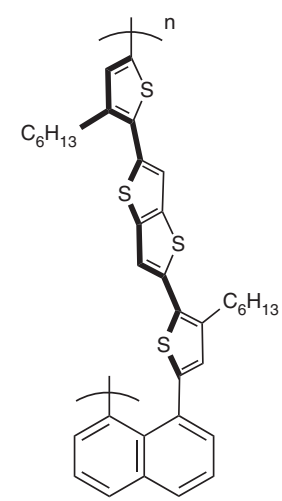

P3

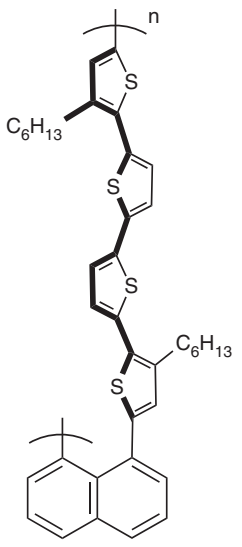

P4

4

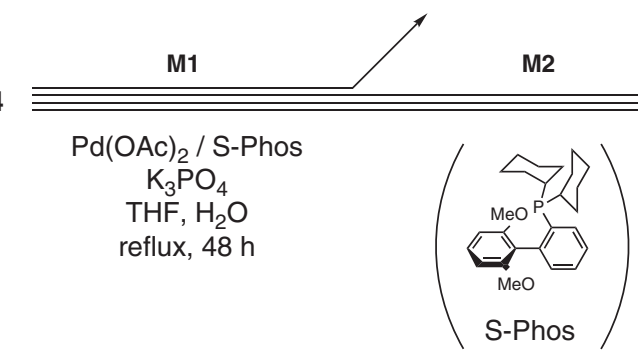

Scheme 2 Synthesis of polymers P1-P4. 


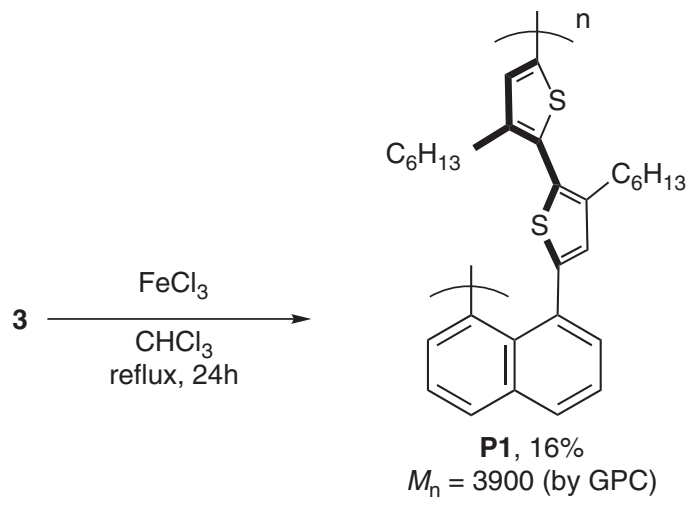

Scheme $\mathbf{3}$ Synthesis of polymer $\mathbf{P} \mathbf{1}$ by the oxidative coupling reaction.

Polymer thin films were readily formed by spin coating or casting from toluene solutions. They were characterized by ${ }^{1} \mathrm{H}$ and ${ }^{13} \mathrm{C}$ NMR spectroscopy, which are shown in Supporting Information. Figure 1 shows the ${ }^{1} \mathrm{H}$ NMR spectrum of $\mathbf{P} 2$ in $\mathrm{CDCl}_{3}$ as a representative example. The signals attributable to hexyl protons appeared at around $0.8,1.2,1.5$ and 2.5 p.p.m. The signals for the terthiophene unit appeared at higher magnetic field at around 6.4-7.0 p.p.m, and those of the naphthalene unit were observed from 7.5 to 8.0 p.p.m. The layered terthiophenes are $\pi$-stacked with each other, which results in the upfield shift of thiophene protons to around 6.4 p.p.m, because of the ring current effect. Such an upfield shift was not observed in the xanthene-based oligothiophene-layered polymers. ${ }^{46}$ The shortest distance between oligothiophene units in the polymers is expected to be $\sim 3 \AA$ based on the X-ray crystal structures of 1,8 -bis $\left(5,2^{\prime}\right.$ bithiophen-2-yl)naphthalene ${ }^{61}$ and bithiophenophane. ${ }^{64,73}$ We also obtained the X-ray crystal structures of $\mathbf{5}$, as shown in Figure 2 (the data are shown in Supporting Information). Thiophene rings adopted the face-to-face structure, and their shortest distance was estimated to be $2.988 \AA$ in the solid state. This distance of $\sim 3 \AA$ is much shorter than the sum of the van der Waals radii of an $\mathrm{sp}^{2}$-carbon (3.4 $\AA$ ); thus $\pi-\pi$ interactions between the layered oligothiophenes of the polymers in solution are expected.

The number-average molecular weights $\left(M_{\mathrm{n}}\right)$ of the polymers were estimated by gel permeation chromatography (polystyrene standards); they are summarized in Table 1 . They were calculated to be $M_{\mathrm{n}}=2200$ 3400 , from which the number-average degrees of polymerization were estimated to be 5-6. The matrix-assisted laser desorption/ionization time-of-flight mass spectrum of polymer P1 was successfully obtained, as shown in Figure 3, although the spectrum was highly broadened. Polymer P1 exhibited a major series of peaks that were regularly separated by the molar mass of a repeating unit $(\mathrm{m} / \mathrm{z} 458)$, which is in accordance with the proposed structure.

The optical properties of polymers P1-P4 were examined, ${ }^{74-77}$ and the data are summarized in Table 2. Figure 4a shows their UV-vis absorption spectra in $\mathrm{CHCl}_{3}\left(1.0 \times 10^{-5} \mathrm{M}\right)$. An increase in the $\lambda_{\text {abs,max }}$ value was observed with increasing thiophene ring number (Table 1 and Figure $4 \mathrm{a})$. The absorption maximum $\left(\lambda_{\mathrm{abs} \text { max }}\right)$ of P1 was observed at $331 \mathrm{~nm}$ (Entry 1 in Table 2 and Figure 4a); this value is almost identical to that of bithiophene-layered oligomers $\left(\lambda_{\text {abs,max }}=330 \mathrm{~nm}\right){ }^{64}$ It is suggested that this absorption band is assigned to the $S_{0} \rightarrow S_{1}$ transition of the bithiophene-naphthalene moiety and the $S_{1}$ state adopts a quinoidal-like structure of thiophene with naphthalene. ${ }^{75,76}$ The bithiophenes in P1 as well as oligothiophenes in P2-P4 have difficulty in rotating freely because of the hexyl

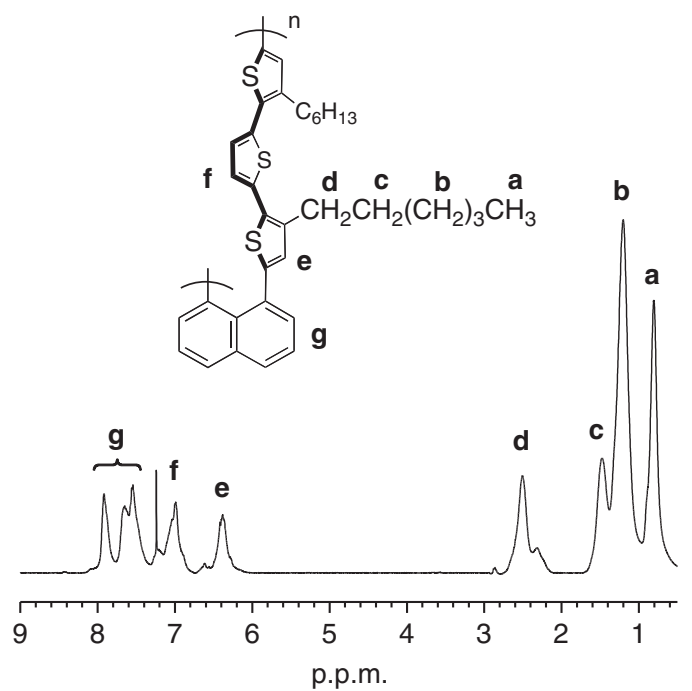

Figure $1{ }^{1} \mathrm{H}$ nuclear magnetic resonance spectrum of polymer $\mathbf{P} 2$ in $\mathrm{CDCl}_{3}$.<smiles>c1csc(-c2cccc3cccc(-c4cccs4)c23)c1</smiles>

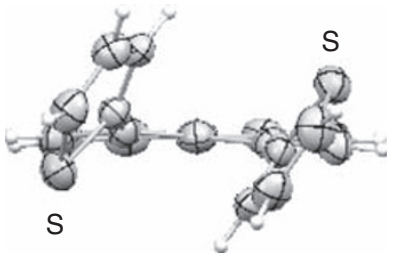

top view

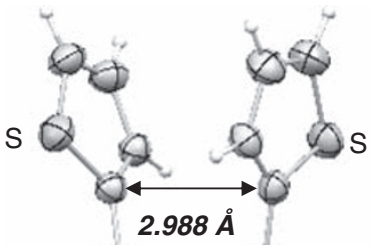

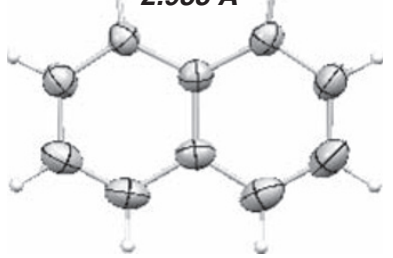

front view
Figure 2 Structure of compound $\mathbf{5}$ and its X-ray crystal structure. Thermal ellipsoids are drawn at the $30 \%$ probability level.

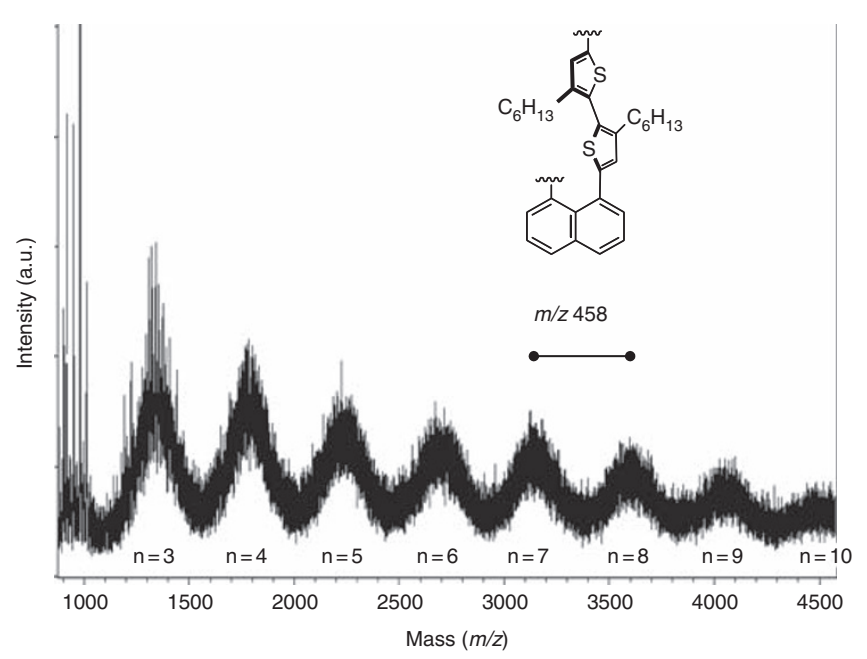

Figure 3 Matrix-assisted laser desorption ionization time-of-flight mass spectrum of polymer $\mathbf{P} \mathbf{1}$ using all-trans-retinoic acid as a matrix. 
Table 2 Optical properties of the polymers

\begin{tabular}{lcccc}
\hline Entry & Polymer & $\lambda_{\text {abs, } \max }(n m)^{\mathrm{a}}$ & $\lambda_{P L, \max }(n m)^{\mathrm{b}}$ & $\Phi_{P L}^{\mathrm{c}}$ \\
\hline 1 & P1 & 331 & 473 & 0.05 \\
2 & P2 & 379 & 529 & 0.18 \\
3 & P3 & 391 & 534 & 0.27 \\
4 & P4 & 410 & 544 & 0.27 \\
\hline
\end{tabular}

aln $\mathrm{CHCl}_{3}, 1.0 \times 10^{-5} \mathrm{M}$.

bIn $\mathrm{CHCl}_{3}, 1.0 \times 10^{-7} \mathrm{M}$, excited at absorption maximum

${ }^{\mathrm{C} A b s o l u t e}$ photoluminescence quantum efficiency.
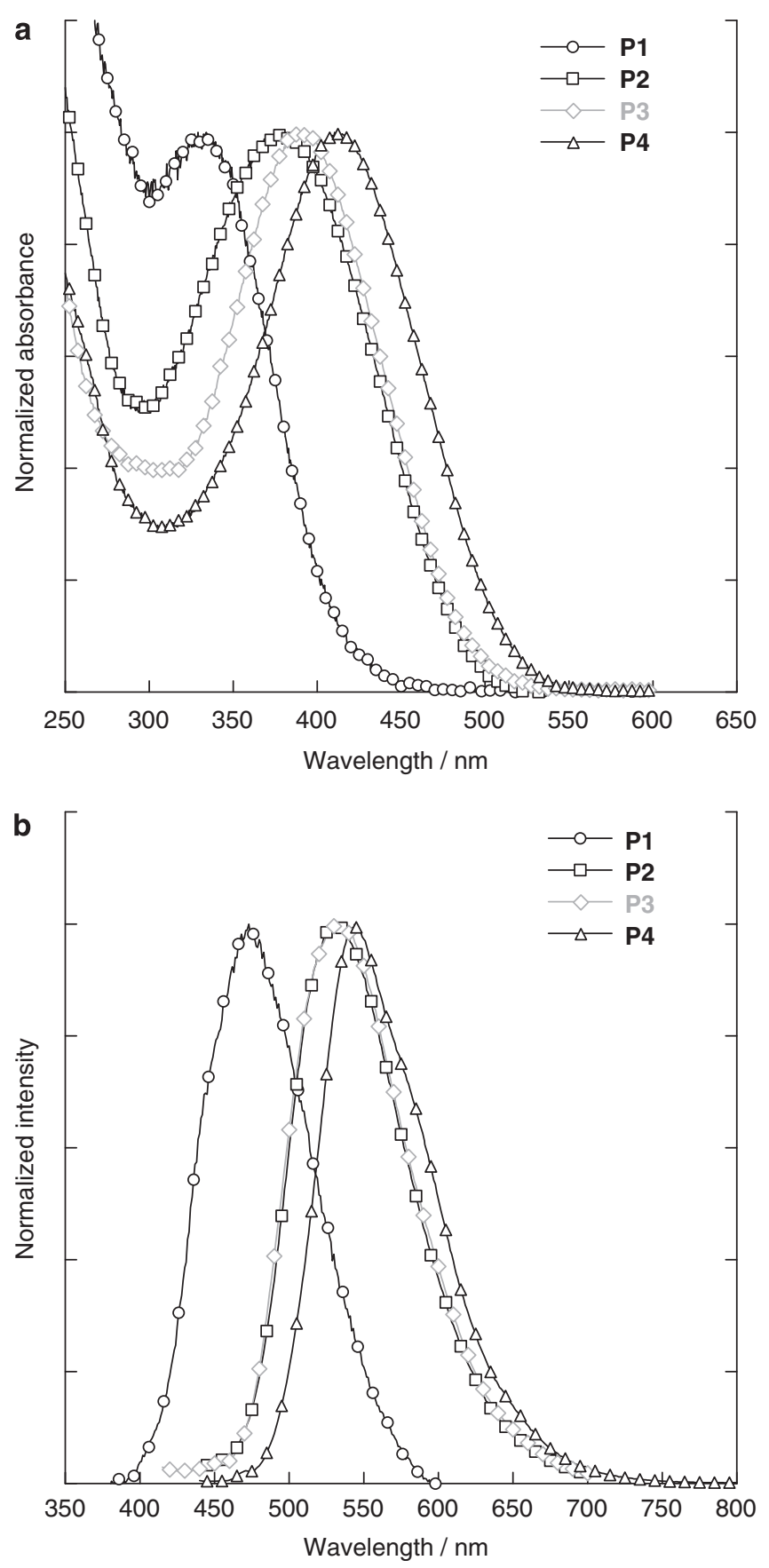

Figure 4 (a) UV-vis absorption spectra in $\mathrm{CHCl}_{3}\left(1.0 \times 10^{-5} \mathrm{M}\right)$ and (b) normalized fluorescence spectra in $\mathrm{CHCl}_{3}\left(1.0 \times 10^{-7} \mathrm{M}\right.$, excited at absorption maxima) of polymers P1-P4. substituent; however, they can twist and have a degree of $\pi$-conjugation with the naphthalenes.

Photoluminescence spectra of $\mathbf{P 1 - P 4}$ in a diluted $\mathrm{CHCl}_{3}$ solution $\left(1.0 \times 10^{-7} \mathrm{M}\right)$ were recorded by the excitation at each absorption maximum (Figure $4 \mathrm{~b}$ ). We found bathochromic shifts of the spectra (Figure $4 \mathrm{~b}$ ) and an increase in the absolute photoluminescence quantum efficiencies $\left(\Phi_{\mathrm{PL}}\right)$ with increasing number of thiophene rings (Table 2).$^{75-77}$ For polymer $\mathbf{P 3}$, which has a rigid fused-ring

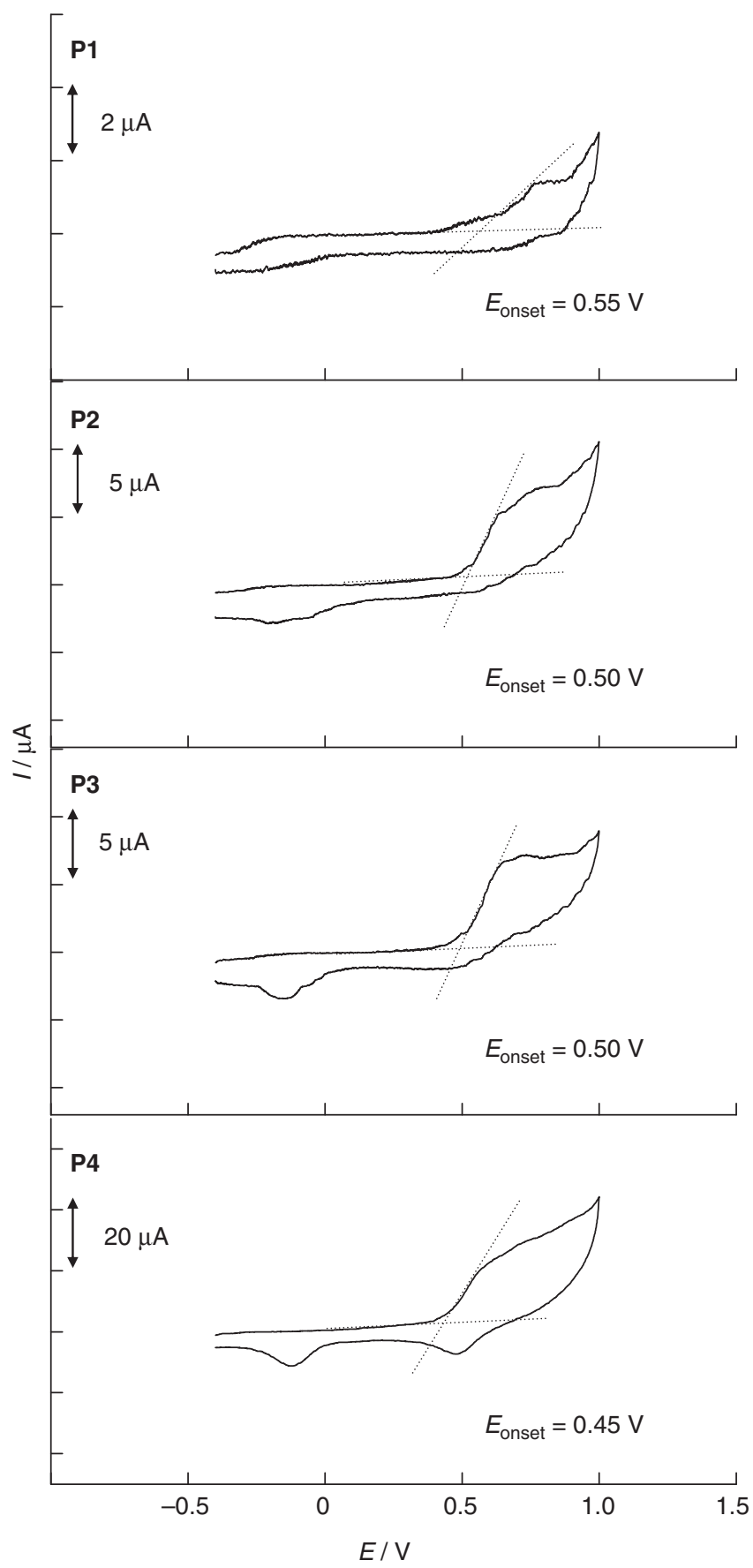

Figure 5 Cyclic voltammograms of polymers $\mathbf{P} 1-\mathbf{P} 4$ in $\mathrm{CH}_{2} \mathrm{Cl}_{2}(0.1 \mathrm{~m})$ containing $\mathrm{Bu}_{4} \mathrm{NClO}_{4}(0.1 \mathrm{M})$ using a glassy carbon working electrode, a Pt counter electrode, a $\mathrm{Ag} / \mathrm{Ag}^{+}$reference electrode, and ferrocene/ferrocenium as an external reference. 
structure, the $\Phi_{\mathrm{PL}}$ value was 0.27 , which was the same as that for $\mathbf{P 4}$ consisting of quaterthiophenes (Entries 3 and 4 in Table 2). The $\Phi_{\mathrm{PL}}$ values of P1, P2 and $\mathbf{P 4}$ were similar to the values found for naphthalene-based bithiophene, terthiophene and quaterthiophene oligomers, ${ }^{75,76}$ respectively. Concentration quenching was not observed among the layered oligothiophenes for P1-P4, suggesting that the main quenching pathway is radiationless intersystem crossing from $S_{1}$ to $T_{1}$. The energy migration and conformational relaxation of the oligothiophene-napththalene moieties within $\sim 100$ picoseconds should be considered for further studies to clarify these points, will be in progress. $^{75,76}$

The electrochemical behaviors of P1-P4 were studied by cyclic voltammetry in $\mathrm{CH}_{2} \mathrm{Cl}_{2}$ containing $0.1 \mathrm{M} \mathrm{Bu}_{4} \mathrm{NClO}_{4}$ with a $\mathrm{Ag} / \mathrm{AgCl}$ $\left(\mathrm{Ag} / \mathrm{Ag}^{+}\right)$reference and a ferrocene/ferrocenium $\left(\mathrm{Fc} / \mathrm{Fc}^{+}\right)$external reference. Their cyclic voltammograms are shown in Figure 5. Irreversible and ambiguous peaks were observed, which impeded the determination of their half-wave potentials $\left(E^{1 / 2}\right)$. The onset potentials $\left(E_{\text {onset }}\right)$ of P1-P4 ranged from $\sim 0.55$ to $0.45 \mathrm{~V}\left(\mathrm{vs} \mathrm{Fc} / \mathrm{Fc}^{+}\right.$); the $E_{\text {onset }}$ values decreased with increasing number of thiophene rings. The highest occupied molecular orbital (HOMO) energy levels of the polymers were estimated from the $E_{\text {onset }}$ values and were found to be approximately -5.35 to $-5.25 \mathrm{eV}^{78}$ Thus, the oligothiophenestacked polymers can be potentially applied in electronic devices such as hole-transporting materials.

In summary, we synthesized naphthalene-based oligothiophenestacked polymers by the Suzuki-Miyaura coupling polymerization. The polymers consist of the stacked oligothiophenes in proximity of $\sim 3.0 \AA$ from each other. The contribution of the quinoidal structure of the oligothiophene units involving the thiophene scaffolds in the excited state resulted in relatively high photoluminescence quantum efficiencies. The electrochemical behaviors of the polymers suggest that they can be potentially applied in electronic devices, such as holetransporting materials and field-effect transistors. Further studies will focus on the control of their higher-ordered structure in the solid state and fabrication of such devices.

\section{ACKNOWLEDGEMENTS}

This work was supported by Grant-in-Aid for Young Scientists (A) (No. 21685012) from the Ministry of Education, Culture, Sports, Science and Technology, Japan.

1 Salaneck, W. R., Clark, D. T. \& Samuelsen, E. J. (eds). Science and Applications of Conducting Polymers, (Adam Hilger: Bristol, 1991).

2 Nalwa, H. S. (ed.) Handbook of Organic Conductive Molecules, (Wiley: Chichester, 1997).

3 Skotheim, T. A., Elsenbaumer, R. L. \& Reynolds, J. R. (eds). Hand book of Conducting Polymers, 3rd edn(Marcel Dekker: New York, 2006).

4 Nakano, T. Synthesis, structure and function of $\pi$-stacked polymers. Polym. J. 42, 103-123 (2010).

5 Nakano, T., Takewaki, K., Yade, T. \& Okamoto, Y. Dibenzofulvene, a 1,1-diphenylethylene analogue, gives a $\pi$-stacked polymer by anionic, free-radical, and cationic catalysts. J. Am. Chem. Soc. 123, 9182-9183 (2001).

6 Nakano, T. \& Yade, T. Synthesis, structure, and photophysical and electrochemical properties of a $\pi$-stacked polymer. J. Am. Chem. Soc. 125, 15474-15484 (2003).

7 Nakano, T., Yade, T., Yokoyama, M. \& Nagayama, N. Charge transport in a $\pi$-stacked poly(divenzofulvene) film. Chem. Lett. 33, 296-297 (2004).

8 Nakano, T., Yade, T., Fukuda, Y., Yamaguchi, T. \& Okumura, S. Free-radical polymerization of divenzofulvene leading to a $\pi$-stacked polymer: structure and properties of the polymer and proposed reaction mechanism. Macromolecules 38, 8140-8148 (2005).

9 Yade, T. \& Nakano, T. Anionic polymerization of 2,7-di-t-butyldivenzofulvene synthesis, structure, and photophysical properties of the oligomers with a $\pi$-stacked conformation. J. Polym. Sci.: Part A: Polym. Chem. 44, 561-572 (2006).

10 Nakano, T. \& Yade, T. Charge delocalization over stacked $\pi$-electron systems. Chem. Lett. 37, 258-259 (2008).
11 Nakano, T., Tanikawa, M., Nakagawa, O., Yade, T. \& Sakamoto, T. Synthesis and structure of an optically active $\pi$-stacked poly(dibenzofulvene) bearing chiral terminal group. J. Polym. Sci.: Part A: Polym. Chem. 47, 239-246 (2009).

12 García Martínez, A., Osío Barcina, J., de Fresno Cerezo, A., Schlüter, A.- D. \& Frahn, J. Synthesis of poly[ $p$-(7-phenylene-7-(2',5'-dihexyl-4-biphenylene))norbornane]: the first soluble polymer with alternating conjugation and homoconjugation. Adv. Mater. 11, 27-31 (1999).

13 Osío Barcina, J., Colorado Heras, M. R., Mba, M., Gómez Aspe, R. \& Herrero-García, N. Efficient electron delocalization mediated by aromatic homoconjugation in 7,7-diphenylnorbornane derivatives. J. Org. Chem. 74, 7148-7156 (2009).

14 Morisaki, Y. \& Chujo, Y. Through-space conjugated polymers based on cyclophanes. Angew. Chem., Int. Ed. 45, 6430-6437 (2006).

15 Morisaki, Y. \& Chujo, Y. Cyclophane-containing polymers. Prog. Polym. Sci. 33, 346-364 (2008).

16 Morisaki, Y. \& Chujo, Y. Synthesis of $\pi$-stacked polymers on the basis of paracyclophane. Bull. Chem. Soc. Jpn. 82, 1070-1082 (2009).

17 Morisaki, Y. \& Chujo, Y. Synthesis of novel $\pi$-conjugated polymers having paracyclophane skeleton in the main chain. Extension of $\pi$-conjugated length via the throughspace. Macromolecules 35, 587-589 (2002).

18 Morisaki, Y. \& Chujo, Y. Synthesis of novel alternating $\pi$-conjugated copolymers having paracyclophane and fluorene units in the main chain leading to the blue light-emitting materials. Chem. Lett. 194-195 (2002).

19 Morisaki, Y., Ishida, T. \& Chujo, Y. Synthesis and properties of novel through-space $\pi$ conjugated polymers based on poly( $p$-phenylenevinylene)s having a paracyclophane skeleton in the main chain. Macromolecules 35, 7872-7877 (2002).

20 Morisaki, Y., Fujimura, F. \& Chujo, Y. Synthesis and properties of novel $\sigma-\pi$ conjugated polymers with alternating organosilicon and paracyclophane units in the main chain. Organometallics 22, 3553-3557 (2003).

21 Morisaki, Y. \& Chujo, Y. Synthesis and properties of a novel through-space conjugated polymer with paracyclophane and ferrocene in the main chain. Macromolecules 36, 9319-9324 (2003).

22 Morisaki, Y., Ishida, T., Tanaka, H. \& Chujo, Y. Synthesis and properties of the paracyclophane-containing conjugated polymer with benzothiadiazole as an electron accepter. J. Polym. Sci.: Part A: Polym. Chem. 42, 5891-5899 (2004).

23 Morisaki, Y. \& Chujo, Y. Novel paracyclophane-fluorene-based conjugated copolymers: synthesis, optical, and electrochemical properties. Macromolecules 37, 4099-4103 (2004).

24 Morisaki, Y. \& Chujo, Y. Novel through-space conjugated polymers consisting of alternate paracyclophane and fluorene. Bull. Chem. Soc. Jpn. 78, 288-293 (2005).

25 Morisaki, Y., Shiotani, Y., Lin, L. \& Chujo, Y. Synthesis of PAMAM dendrimers possessing paracyclophane on their surface. Polym. J. 40, 779-783 (2008).

26 Wada, N., Morisaki, Y. \& Chujo, Y. Polymethylenes containing paracyclophane in the side chain. Macromolecules 42, 1439-1442 (2009).

27 Morisaki, Y., Lin, L. \& Chujo, Y. Synthesis of cyano-substituted through-space poly( $p$ arylenevinylene). Chem. Lett. 38, 734-735 (2009).

28 Morisaki, Y., Lin, L. \& Chujo, Y. Synthesis and properties of through-space conjugated polymers based on cyano-substituted poly(p-arylenevinylene)s. J. Polym. Sci.: Part A: Polym. Chem. 47, 5979-5988 (2009).

29 Lin, L., Morisaki, Y. \& Chujo, Y. Synthesis of through-space conjugated polymers containing paracyclophane and thienopyrazine in the main chain. J. Polym. Sci.: Part A: Polym. Chem. 47, 7003-7011 (2009).

30 Guyard, L. \& Audebert, P. Synthesis and electrochemical polymerization of bis-dithienyl cyclophane. Electrochem. Commun. 3, 164-167 (2001).

31 Guyard, L., Audebert, P., Dolbier, W. R. Jr. \& Duan, J.- X. Synthesis and electrochemical polymerization of new oligothiophene functionalized fluorocyclophane. J. Electroanal. Chem. 537, 189-193 (2002).

32 Salhi, F., Lee, B., Metz, C. \& Bottomley, L. A. Influenece of $\pi$-stacking on the redox properties of oligothiophenes: ( $\alpha$-alkyloligo-thienyl)paracyclophane. Org. Lett. 4, 3195-3198 (2002).

33 Salhi, F. \& Collard, D. M. $\pi$-Stacked conjugated polymers: the influence of paracyclophane $\pi$-stackes on the redox and optical properties of a new class of broken conjugated polythiophenes. Adv. Mater. 15, 81-85 (2003).

34 Mizogami, S. \& Yoshimura, S. Synthesis of a new polycojugated system: polycyclophane. J. Chem. Soc., Chem. Commun. 427-428 (1985).

35 Mizogami, S. \& Yoshimura, S. Synthesis of a new crystalline polymer: polymetacyclophane. J. Chem. Soc., Chem. Commun. 1736-1737 (1985).

36 Nugent, H. M., Rosenblum, M. \& Klemarczky, P. Synthesis of face-to-face metallocene polymers. J. Am. Chem. Soc. 115, 3848-3849 (1993).

37 Rosenblum, M., Nugent, H. M., Jang, K.- S., Labes, M. M., Cahalane, W., Klemarczyk, P. \& Reiff, W. M. The synthesis and properties of face-to-face metallocene polymers. Macromolecules 28, 6330-6342 (1995).

38 Hudson, R. D. A., Foxman, B. M. \& Rosenblum, M. Synthesis and properties of new stacked metallocene polymers. Organometallics 18, 4098-4106 (1999).

39 Jenekhe, S. A., Alam, M. M., Zhu, Y. \& Jiang, S. Single-molecule nanomaterials from $\pi$ stacked side-chain conjugated polymers. Adv. Mater. 19, 536-542 (2007).

40 Morisaki, Y. \& Chujo, Y. Construction of benzene ring-layered polymers. Tetrahedron Lett. 46, 2533-2537 (2005).

41 Morisaki, Y., Murakami, T. \& Chujo, Y. Synthesis and properties of paracyclophanelayered polymers. Macromolecules 41, 5960-5963 (2008).

42 Morisaki, Y., Murakami, T. \& Chujo, Y. Synthesis, structure, and properties of aromatic ring-layered polymers containing ferrocene as a terminal unit. J. Inorg. Organomet. Polym. Mater. 19, 104-112 (2009).

43 Morisaki, Y., Murakami, T., Sawamura, T. \& Chujo, Y. Paracyclophane-layered polymers end-capped with fluorescence quenchers. Macromolecules 42, 3656-3660 (2009). 
44 Morisaki, Y., Imoto, H., Miyake, J. \& Chujo, Y. Synthesis and properties of oligophenylene-layered polymers. Macromol. Rapid Commun. 30, 1094-1100 (2009).

45 Morisaki, Y., Fernandes, J. A., Wada, N. \& Chujo, Y. Synthesis and properties of carbazole-layered polymers. J. Polym. Sci.: Part A: Polym. Chem. 47, 4279-4288 (2009).

46 Morisaki, Y., Fernandes, J. A. \& Chujo, Y. Synthesis of oligothiophene-layered polymers.. Macromol. Rapid Commun. 30, 2107-2111 (2009).

47 Morisaki, Y., Sawamura, T., Murakami, T. \& Chujo, Y. Synthesis of anthracene-stacked oligomers and polymer. Org. Lett. 12, 3188-3191 (2010).

48 Oligothiophene-layered polymers based on o-substituted benzene have been reportedTovar, J. D. \& Swager, T. M. Cofacially constrained organic semiconductors.. J. Polym. Sci.: Part A: Polym. Chem. 41, 3693-3702 (2003).

49 Oligothiophene-layered polymers based on calyxarenasYu, H.- H. Xu, B. \& Swager, T. M. A proton-doped calixarene-based conducting polymer. J. Am. Chem. Soc. 125, 1142-1143 (2003), See also reference 50..

50 Yu, H.-h., Pullen, A. E., Büschel, M. G. \& Swager, T.M. Conducting Polymer Actuator Mechanism Based on the Conformational Flexibility of Calix[4]arene. Angew. Chem., Int. Ed. 43, 3700-3703 (2004).

51 Vinyl polymers containing oligothiophenes in the side chain were synthesized; see Melucci, M. Barbarella, G. Zambianchi, M. Benzi, M. Biscarini, F. Cavallini, M. Bongini, A. Fabbroni, S. Mazzeo, M. Anni, M. \& Gigli, G. Poly( $\alpha$-vinyl- $\omega$-alkyloligothiophene) side-chain polymers. synthesis, fluorescence, and morphology. Macromolecules 37, 5692-5702 (2004).

52 Sangvikar, Y., Fischer, K., Schmidt, M., Schlüter, A. D. \& Sakamoto, J. Suzuki polycondensation with a hairpin monomer. Org. Lett. 11, 4112-4115 (2009).

53 Chou, C.- M., Lee, S.- L., Chen, C.- H., Biju, A. T., Wang, H. W., Wu, Y. L., Zhang, G.- F., Yang, K.- W., Lim, T- S., Huang, M- J., Tsai, P.- Y., Lin, K.- C., Huang, S.- L., Chen, C.-h. \& Luh, T.- Y. Polymeric Ladderphanes. J. Am. Chem. Soc. 131, 12579-12585 (2009).

54 Schuster, G. B. (ed.) Long-range Charge Transfer in DNA I \& // (Springer: Berlin, 2004).

55 Sundar, V. C., Zaumseil, J., Podzorov, V., Menard, E., Willett, R. L., Someya, T., Gershenson, M. E. \& Rogers, J. A. Elastomeric transistor stamps: reversible probing of charge transport in organic crystals. Science 303, 1644-1646 (2004).

56 Otsubo, T., Mizogami, S., Otsubo, I., Tozuka, Z., Sakagami, A., Sakata, Y. \& Misumi, S. Layered compounds. XV. synthesis and properties of multilayered cyclophanes. Bull. Chem. Soc. Jpn. 46, 3519-3530 (1973).

57 Misumi, S. \& Otsubo, T. Chemistry of multilayered cyclophanes. Acc. Chem. Res. 11, 251-256 (1978).

58 Shibahara, M., Watanabe, M., Iwanaga, T. \& Shinmyozu, T. Synthesis, structure, and transannular $\pi-\pi$ interaction of multilayered metacyclophanes. J. Org. Chem. 72, 2865-2877 (2007).

59 Shibahara, M., Watababe, M., Iwanaga, T., Matsumoto, T., Ideta, K. \& Shinmyozu, T. Synthesis, structure, and transannular $\pi-\pi$ interaction of three- and four-layered paracyclophanes. J. Org. Chem. 73, 4433-4442 (2008).

60 Kuroda, M., Nakayama, J. \& Hoshino, M. Synthesis and properties of naphthalenes carrying two cofacially oriented $\alpha$-oligothiophene units at the peri positions. Tetrahedron Lett. 33, 7553-7556 (1992).

61 Kuroda, M., Nakayama, J. \& Hoshino, M. Synthesis and properties of 1,8-di(2-thienyl)-,

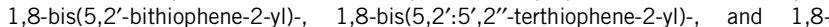
bis $\left(5,2^{\prime}: 5^{\prime}, 2^{\prime \prime}: 5^{\prime \prime}, 2^{\prime \prime \prime}\right.$-quaterthiophene-2-yl)naphthalenes and related compounds. Tetrahedron 49, 3735-3748 (1993).
62 Kuroda, M., Nakayama, J., Hoshino, M., Furusho, N. \& Ohba, S. Synthesis and properties of $\alpha$-oligothiophenes carrying three cofacially oriented thiophene rings through peri positions of naphthalenes. Tetrahedron Lett. 35, 3957-3960 (1994).

63 Iyoda, M., Nakao, K., Kondo, T., Kuwatani, Y., Yoshida, M., Matsuyama, H., Fukami, K. \& Nagase, S. (1,8)Naphthalenophane containing 2,2'-bithienyl-5,5'-ylene bridges. Tetrahedron Lett. 42, 6869-6872 (2001).

64 Nakao, K., Nishiguchi, T. \& lyoda, M. Syntheses, structures, and properties of bithiophenophanes bridged at 1,8-positions of naphthalenes. Heterocycles 76, 727-745 (2008).

65 Pangborn, A. B., Giardello, M. A., Grubbs, R. H., Rosen, R. K. \& Timmers, F. J. Safe and convenient procedure for solvent purification. Organometallics 15, 1518-1520 (1996).

66 House, H. O., Koepsell, D. G. \& Campbell, W. J. Synthesis of some diphenyl and triphenyl derivatives of anthracene and naphthalene. J. Org. Chem. 37, 1003-1011 (1972).

67 Tang, W., Singh, S. P., Ong, K. H. \& Chen, Z.- K. Synthesis of thienothiophene derived conjugated oligomers for field-effect transistors applications. J. Mater. Chem. 20, 1497-1505 (2010).

68 Miyaura, N. \& Suzuki, A. Stereoselective synthesis of arylated ( $E$ )-alkenes by the reaction of alk-1-enylboranes with aryl halides in the presence of palladium catalyst. J. Chem. Soc., Chem. Commun. 866-867 (1979).

69 Miyaura, N. \& Suzuki, A. Palladium-catalyzed cross-coupling reactions of organoboron compounds. Chem. Rev. 95, 2457-2483 (1995).

70 Walker, S. D., Barder, T. E., Martinelli, J. R. \& Buchwald, S L A Rationally designed universal catalyst for Suzuki-Miyaura coupling processes. Angew. Chem., Int. Ed. 43, 1871-1876 (2004).

71 Negishi, E. In: Handbook of Organopalladium Chemistry for Organic Synthesis, (ed. Negishi, E.) 229-247, (Wiley-VCH: New York, 2002).

72 Arbizzani, C., Bongini, A., Mastragostino, M., Zanelli, A., Barbarella, G. \& Zambianchi, M. Polyalkylthiophenes as electrochromic materials: a comparative study of poly (3-methylthiophenes) and poly(3-hexylthiophenes). Adv. Mater. 7, 571-574 (1995).

73 Synthesis and X-ray crystal structures of 3,4-di(2-thienyl)-7,7-7 H-2,5-dithia-7-silacyclopenta[a]pentalene was reported, in which the shortest distance between two thiophene rings was $3.44 \AA$; seelyoda, M. Copper-mediated aryl-aryl couplings for the construction of oligophenylenes and related heteroaromatics. Adv. Synth. Catal. 351, 984-998 (2009).

74 Xu, B. \& Holdcroft, S. Molecular control of luminescence from poly(3-hexylthiophenes). Macromolecules 26, 4457-4460 (1993).

75 Seixas de Melo, J., Silva, L. M. \& Kuroda, M. Photophysical and theoretical studies of naphthalene-substituted oligothiophenes. J. Chem. Phys. 115, 5625-5636 (2001).

76 Pina, J. \& Seixas de Melo, J. A comprehensive investigation of the electronic spectral and photophysical properties of conjugated naphthalene-thiophene oligomers. Phys. Chem. Chem. Phys. 11, 8706-8713 (2009).

77 Chosrovian, H., Rentsch, S., Grebner, D., Dahm, D. U. \& Birckner, E. Time-resolved fluorescence studies on thiophene oligomers in solution. Synth. Met. 60, 23-26 (1993).

78 These values were calculated from the $E_{\text {onset }}$ of the polymers and the energy level of $\mathrm{Fc} / \mathrm{FC}^{+}(4.80 \mathrm{eV})$, namely $\mathrm{HOMO}=-4.80-E_{\text {onset. }}$ For example, see Pommerehne, J., Vestweber, H., Guss, W., Mahrt, R. F., Bässler, H., Porsch, M., \& Daub, J. Efficient two layer LEDs on a polymer blend basis. Adv. Mater. 7, 551-554 (1995).

Supplementary Information accompanies the paper on Polymer Journal website (http://www.nature.com/pj) 